\title{
ANALISIS SENTIMEN KOMENTAR FACEBOOK BERBASIS LEXICON DAN SUPPORT VECTOR MACHINE
}

\author{
Iin Kurniasari*, Kusrini**, Hanif AlFatta* \\ * MTI, Amikom Yogyakarta University \\ ** MTI, Amikom Yogyakarta University \\ *** Departemen Ilmu Komputer, Amikom Yogyakarta University
}

\begin{tabular}{|c|c|}
\hline Info Artikel : & ABSTRACT \\
\hline \multirow[t]{2}{*}{$\begin{array}{l}\text { Sejarah Artikel : } \\
\text { Menerima : } \\
\text { 27 Juli } 2020 \\
\text { Revisi : } \\
\text { 29 Juli } 2020 \\
\text { Diterima : } \\
\text { 06 Agust } 2020 \\
\text { Online : } \\
\text { 14 Agust } 2020 \\
\text { Keyword : } \\
\text { Sentiment } \\
\text { Analysis, } \\
\text { Facebook, SVM, } \\
\text { Lexicon }\end{array}$} & $\begin{array}{l}\text { Facebook is one of the social media that is often used. Especially in the } \\
\text { current co-19 pandemic. Lots of public sentiments were issued, especially on } \\
\text { Facebook in the form of comments on existing information about Covid-19 } \\
\text { which is challenging to analyze for several purposes. The NLP (Natural } \\
\text { Language Processing) technique which consists of casefolding, tokenizing, } \\
\text { filtering and stemming can be used in this case. This study discusses the } \\
\text { development of sentiment analysis on Facebook using Lexicon and Support } \\
\text { Vector Machine. The Lexicon data obtained has lower accuracy using the } \\
\text { Vector Support Engine. }\end{array}$ \\
\hline & INTISARI \\
\hline $\begin{array}{l}\text { Kata Kunci : } \\
\text { Analisis } \\
\text { Sentimen, } \\
\text { Facebook, SVM, } \\
\text { Lexicon }\end{array}$ & $\begin{array}{l}\text { Facebook adalah salah satu media sosial yang sering digunakan. Terutama } \\
\text { pada pandemi co-19 saat ini. Banyak sekali sentimen publik yang beredar, } \\
\text { terutama di Facebook dalam bentuk komentar atas informasi yang ada tentang } \\
\text { covid-19 yang menantang untuk dianalisis untuk beberapa tujuan. Teknik NLP } \\
\text { (Natural Language Processing) yang terdiri dari casefolding, tokenizing, } \\
\text { filtering dan stemming dapat digunakan dalam kasus ini. Studi ini berfokus } \\
\text { pada pengembangan analisis sentimen di Facebook menggunakan Lexicon } \\
\text { dan Support Vector Machine. Data Lexicon yang diperoleh memiliki akurasi } \\
\text { lebih rendah daripada menggunakan Support Vector Machine. }\end{array}$ \\
\hline
\end{tabular}




\section{PENDAHULUAN}

Media sosial dewasa ini dijadikan sebagai bahan referensi bagi perusahaan untuk melihat perilaku customernya (Jeong: 2018). Analisis data facebook juga dapat digunakan sebagai referensi untuk menentukan langkah-langkah bisnis perusahaan dalam menentukan kebijakannya. Analisis ini dilakukan dengan mencari pendapat atau sentimen dari beberapa kalimat atau komentar yang didapat. Oleh karena itu, tumpukan data teks ini di Facebook cukup berharga karena menyimpan informasi yang berharga. Untuk mengungkap informasi ini, penambangan data perlu dilakukan dengan menggunakan teknik tertentu. Penambangan data ini dapat dilakukan dengan menggunakan teknik penambangan teks yang dapat dikombinasikan juga menggunakan pendekatan Natural Language Preprocessing. Selanjutnya, data penting yang telah ditambang perlu ditentukan oleh jenis sentimen. Ini dilakukan dengan menggunakan sentimen analitis.

Facebook adalah salah satu jenis media sosial yang banyak digunakan. Pengguna menggunakan Facebook untuk menyampaikan komentar mereka kepada masyarakat umum. Jumlah pengguna Facebook telah mencapai 2,45 milyar orang di seluruh dunia (Laksito: 2018). Komentar yang disampaikan bisa dalam bentuk berita, opini, argumen, dan beberapa jenis kalimat lainnya (Cathuryedi: 2018). Ini menyebabkan facebook menjadi kaya akan teks yang memiliki data tertentu.

Pada umumnya, seseorang menginginkan pendapat dari orang lain sebagai masukan untuk menentukan keputusan. Pendapat ini bisa dilakukan dengan bertanya langsung. Dengan bertanya secara langsung, dibutuhkan waktu dan upaya untuk bertemu orang-orang yang diyakini bertanya. Cara lain adalah dengan mendapatkan pendapat dari Facebook. Pendapat dalam bentuk komentar yang disediakan oleh Facebook. Namun, pendapat ini harus dibedakan berdasarkan jenis opini positif, negatif, dan netral. Selain itu, komentar ini belum dikelompokkan berdasarkan kategori yang ingin Anda temukan. Jadi, itu masih tersebar luas dan perlu diidentifikasi.

\section{METODE PENELITIAN}

Desain penelitian ini adalah eksperimental. Penelitian eksperimental adalah penelitian yang memanipulasi atau mengendalikan situasi alam dengan membuat kondisi buatan. Pembuatan kondisi ini dilakukan oleh peneliti. Dengan demikian, penelitian eksperimental adalah penelitian yang dilakukan dengan memanipulasi objek penelitian, serta kontrol yang disengaja terhadap objek penelitian. Selain itu, dalam penelitian eksperimental ada tiga elemen penting yang harus diperhatikan dalam melakukan penelitian ini, yaitu kontrol, manipulasi, dan observasi. Variabel kontrol di sini adalah inti dari metode eksperimental, karena variabel kontrol inilah yang akan menjadi standar dalam melihat apakah ada perubahan, atau perbedaan yang terjadi karena perbedaan perlakuan yang diberikan.

Alur penelitian ini ditunjukkan pada Gambar 4. Penelitian ini bersifat eksperimental atau eksperimental. Penelitian ini dimulai dengan studi literatur di bidang NLP dan Analisis Sentimen. Kemudian, data dikumpulkan. Data dikumpulkan dalam bentuk kumpulan komentar yang diambil melalui penggunaan Facebook API. Data yang diambil adalah dalam bentuk teks yang disimpan dalam database. Kemudian, lanjutkan ke analisis data. Data yang dianalisis dilakukan secara deskriptif. Hasil analisis adalah dalam bentuk daftar kata sifat bersama dengan pelabelan manual yang digunakan sebagai leksikon dan merancang sistem analisis sentiment dengan menggunakan Support Vector Machine.

ISSN Print $\quad$ : 1979-7141

ISSN Online : 2541-1942 


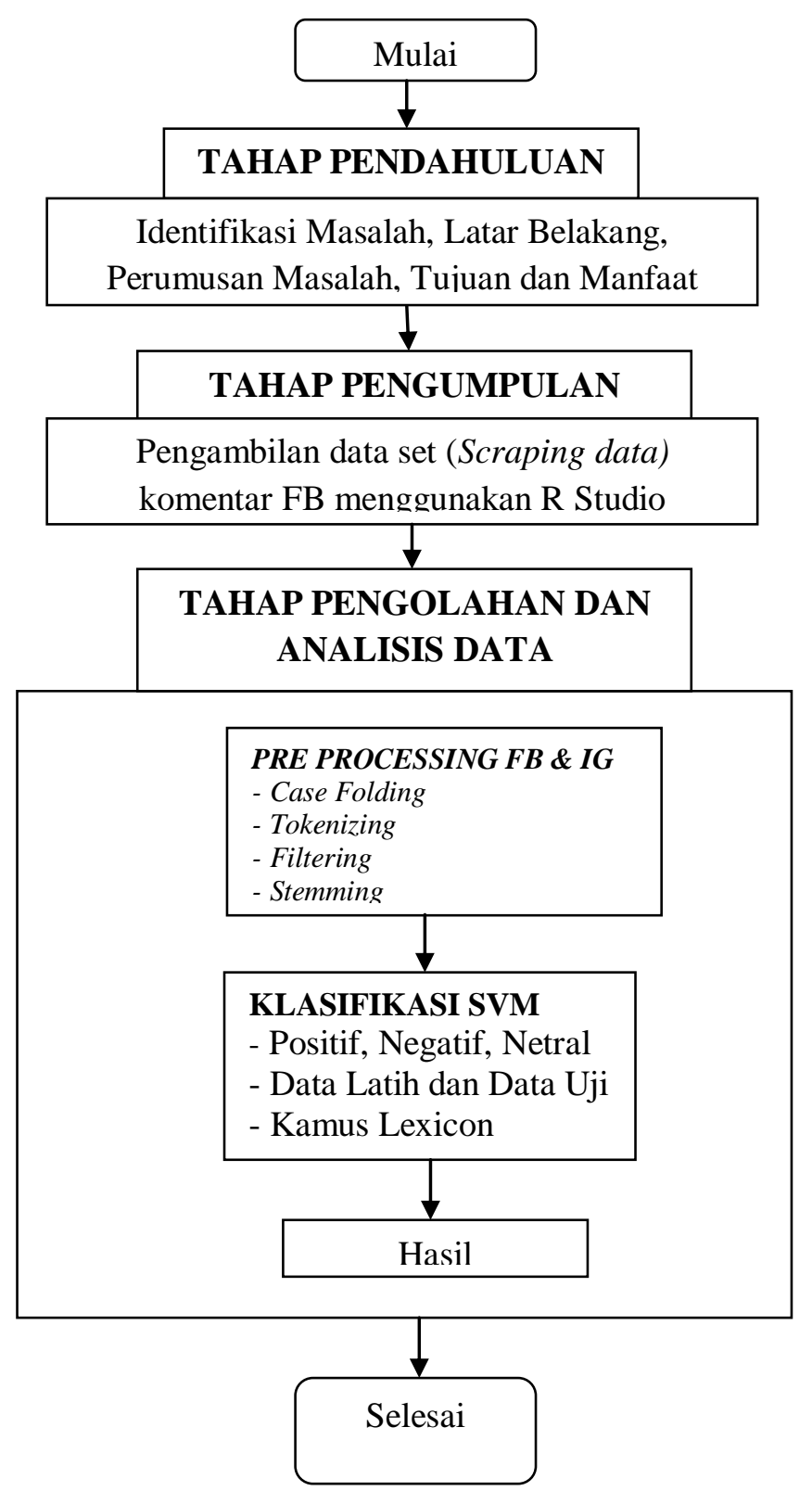

Gambar 1. Alur Penelitian

\section{HASIL DAN ANALISA}

Setelah melakukan penelitian sesuai dengan metode penelitian yang telah ditentukan, hasil penelitian ini diperoleh dengan menggunakan alat bahasa pemrograman Python dan API facebook kemudian API facebook diatur untuk mendapatkan sebanyak 100 komentar. Langkah awal menggunakan sistem dilakukan dengan memasukkan topik pada sistem dihasilkan sebanyak 100 dari 65 komentar yang termasuk dalam klasifikasi positif. Selanjutnya, 23 komentar termasuk dalam klasifikasi negatif sementara 12 komentar termasuk dalam klasifikasi netral. Dalam penelitian ini 250 dataset bahasa Inggris disediakan dan 112 kata sifat digunakan sebagai leksikon. Kemudian, ini dilakukan dengan pengujian untuk mengetahui daya ingat, presisi, dan akurasi sentimen ini.

Tabel I 
Evaluasi Analisis Sentimen berbasis Lexicon

\begin{tabular}{|l|c|c|c|}
\hline \multirow{2}{*}{ Kategori } & \multicolumn{3}{|c|}{ Tipe Kategori } \\
\cline { 2 - 4 } & Positif & Negatif & Netral \\
\hline Presision & $62 \%$ & $67 \%$ & $13 \%$ \\
\hline Recall & $62 \%$ & $47 \%$ & $36 \%$ \\
\hline Accuracy & $64 \%$ & $66 \%$ & $75 \%$ \\
\hline
\end{tabular}

Tabel II

Analisis Sentimen dengan Support Vector Machine

\begin{tabular}{|l|l|l|l|}
\hline $\begin{array}{l}\text { Data } \\
\text { Training }\end{array}$ & $\begin{array}{l}\text { Data } \\
\text { Testing }\end{array}$ & Acuracy & Presision \\
\hline 250 & 100 & $89 \%$ & $89 \%$ \\
\hline 350 & 150 & $84 \%$ & $83 \%$ \\
\hline
\end{tabular}

\section{KESIMPULAN}

Analisis Sentimen menggunakan pendekatan Lexicon memiliki akurasi lebih rendah daripada menggunakan Support Vector Machine. Ini karena jumlah kata sifat dalam Lexicon masih belum lengkap dan metode Lexicon lebih sederhana daripada metode yang ada pada Support Vector Machine. Kedepannya diperlukan penelitian lebih lanjut dengan menggunakan metode yang lain seperti KNN, 


\section{DAFTAR PUSTAKA}

Alhajji, Moehammad. 2020. "Sentiment Analysis of Tweets in Saudi Arabia Regarding Governmental Preventive Measures to Contain COVID-19". preprints

Athira, Wanda. 2018. "Analisis Sentimen Cyberbullying Pada Komentar Instagram Dengan Metode Klasifikasi Support Vector Machine”. Jurnal Pengembangan Teknologi Informasi dan Ilmu Komputer

Budi, Eko. 2019. “Analisis Sentimen Calon Presiden Indonesia 2019. Berdasarkan Komentar Publik Di Facebook". Jurnal Eksplora Informatika

Burhanudin, Ikhsan. 2020. "Ancaman Krisis Ekonomi Global Dari Dampak Penyebaran Virus Corona (Covid 19)". Akmen

Fatmawati. 2017. "Klasifikasi Keluhan Menggunakan Metode Support Vector Machine (SVM) (Studi Kasus: Akun Fb Group Iraise Helpdesk)". Jurnal CoreIT

Fauzi, Akhmad. 2019. "Sentimen Analisis Berinternet Pada Media Sosial Dengan Menggunakan Algoritma Bayes". Jurnal Informatika

S. Y. Yoo, J. I. Song, and O. R. Jeong, "Social media contents based sentiment analysis and prediction system," Expert Syst. Appl., vol. 105, pp. 102-111, 2018.

A. D. Laksito et al., "A Comparison Study of Search Strategy on Collecting Twitter Data for Drug Adverse Reaction,” 2018 Int. Semin. Appl. Technol. Inf. Commun., pp. 356-360, 2018.

I. Chaturvedi, E. Cambria, R. E. Welsch, and F. Herrera, "Distinguishing between facts and opinions for sentiment analysis: Survey and challenges," Inf. Fusion, vol. 44, pp. 65-77, 2018.

R. Bandana, "Sentiment Analysis of Movie Reviews Using Heterogeneous Features," 2018 2nd Int. Conf. Electron. Mater. Eng. Nano-Technology, pp. 1-4, 2018. 